\title{
Sosyal Bilgiler Öğretmenlerinin Öğretmenlik Mesleği Seminerlerine İliş̧kin Görüşleri
}

\author{
Mehmet ORAN $N^{l} \&$ Mesut IŞIKLI ${ }^{2}$
}

\section{Özet}

$\mathrm{Bu}$ araştırma, Manisa ili Kula ilçesinde görev yapan Sosyal Bilgiler öğretmenlerinin öğretmenlik mesleği seminerlerine iliş̧in düşüncelerini ortayı çıkarmayı amaçlamaktadır. Araştırmada nitel araştırma desenlerinden olgubilim modeli uygulanmıştır. Araştırmayı diğer çalışmalardan ayıran ve farklı kılan tarafi; bu konu hakkında Sosyal Bilgiler öğretmenlerinin görüşlerini ortaya koyan çalışmaların sayısının az olması ve bu çalışmanın bu eksikliği gidermeye çalışmasıdır. Araştırma kapsamında 13 Sosyal Bilgiler öğretmenine yarı yapılandırılmış mülakat formu uygulanmıştır. Verilerin analizinde cevaplar ilk önce 48 kodda toplanmıș, daha sonra bu sayı 19'a indirilmiștir. Araştırmanın sonunda ise; öğretmenlik mesleği seminerleri kapsamında uzman ve akademisyenlerle daha çok etkileşim halinde olunup piknik, doğa yürüyüşü, müze ziyareti gibi etkinlik ve faaliyetlerin daha fazla yer verilmesinin daha yararlı olabileceği fikri üzerinde durulmuştur.

Anahtar Sözcükler: Sosyal Bilgiler, Sosyal Bilgiler Öğretmeni, Seminer,

\section{Opinions of Social Studies Teachers on Teaching Profession Seminars}

\begin{abstract}
This study aims to reveal the opinions of the Social Studies teachers working in Kula district of Manisa about the teaching profession seminars. Phenomenology model, one of the qualitative research designs, was applied in the study. What distinguishes the research from other studies and makes it different; the lack of a study demonstrating the views of Social Studies teachers on this subject and this study tries to overcome this deficiency.In the scope of the research, semistructured interview forms were applied to 13 Social Studies teachers.In the analysis of the data, the answers were first collected in 48 codes and then this number was reduced to 19 . At the end of the research; Within the scope of teaching profession seminars, it was emphasized that it would be more beneficial to have more interaction with experts and academicians and to include more activities and activities such as picnic, hiking, museum visit.
\end{abstract}

Key Words: Social Studies, Social Studies Teacher, Seminar,

\footnotetext{
${ }^{1}$ Dr., mehmtoran@gmail.com

2 Arş. Gör., Uşak Üniversitesi, Eğitim Fakültesi, Türkçe ve Sosyal Bilimler Eğitimi Bölümü, Sosyal Bilgiler Eğitimi ABD, mesut.i@usak.edu.tr
} 


\section{Giriş}

İnsanoğlu varoluşundan itibaren bugüne kadar meydana getirdiği ürünleri, değerleri, bilgileri ve becerileri nesilden nesile aktarırken eğitime çok büyük görev ve sorumluluklar düşmektedir. Çünkü uygarlıkların ve toplumların birbirinden haberdar olması planlı veya plansız eğitim süreci ile gerçekleşebilmektedir (Başar, 2007: 25).

Eğitim, toplumlar tarafindan belirlenmiş ve bireylerde kazandırılması düşünülen davranışların tamamına verilen addır (MEB, 2008: 3). Eğitim, önceden belirlenmiş amaçlar doğrultusunda insan davranışlarında istendik yönde meydana gelmesi hedeflenen davranış değişiklikleridir (Fidan, 2012: 4). Şahin (2001: 9) ise eğitimi; bireylerin mesleki ve akademik gelişimlerini kazanmalarıyla birlikte, sosyal ve bireysel olarak çevreye uyumları amacıyla gerekli olan becerilerinin geliştirilmesi olarak adlandırmıştır.

Bir ülkenin gelişim gösterebilmesi, o ülkede yaşayan vatandaşların eğitilip ülkenin hedeflerine uygun yetenek ve becerilerin kazandırılabilmesiyle gerçekleşebilmektedir. Bundan dolayı eğitim; sosyal yapıların oluşması ve insanların yaşamlarını etkilemesi noktasında önemli etkiye sahiptir (Nalçacı, 2001: 6). Ayrıca bilgi karmaşıklığını ortadan kaldırıp geleceğe güvenle bakabilmek adına genç nesillere eğitimi iyi vermek zorunludur (Keskin, 2009: 108). Eğitimin iyi bir şekilde verilebilmesi için de öğretmenlere büyük görevler düşmektedir.

Öğretmenler öğretim süreçlerinde rol alırken bir takım yeterliklere sahip olmalıdırlar. Öğretmenler alanları ile ilgili bilgi ve becerilerle donanmış olmalıdırlar ve öğrencilerine de benzeri bilgi ve becerileri kazandırmak için çalışmalıdırlar. Öğrenme öğretme süreçlerinde öğretmenlere düşen görevlerden bir tanesi de öğretim teknolojilerini ve araç gereçlerini öğrencilerin düşünme yeteneklerini üst seviyelere taşıyacak şekilde yapılandırmalıdırlar. Öğretmenler öğrencilerinin motivasyonlarını artırmak, özgüven kazanmalarını sağlamak, öz değerlendirmelerine firsat vermek için destekleyici etkinliklerde bulunmalıdırlar (Aydın ve Yılmaz, 2010: 63).

Öğretmenlerin sahip olması gereken bu özellikler ise eğitim-öğretim yılının ortasında ve sonunda öğretmenlik mesleği seminerleri gibi programlarla öğretmenlere kazandırılmaya çalışılmaktadır. Araştırma kapsamında öğretmenlik mesleği seminerleri konusu üzerine yapılan çalışmalara göz attığımızda Gültekin, Güvey Aktay ve Gültekin (2018) ile Genç (2015) gibi bazı yazarların eserlerinin olduğu ve sayıca bu konuda yeterli çalışmaların olmadığı, Sosyal Bilgiler öğretmenlerinin bu konu üzerine görüşlerini ortaya koyan çalışmaların ise henüz kaleme alınmadığ1 görülmüştür. Bu eksikliği gidermeye çalışmak adına araştırmada; öğretmenlik mesleği seminerleri kapsamındaki faaliyetlerinin neler olduğu, bu faaliyetlerin faydalarının neler olduğu, bu faaliyetleri gerçekleştirirken ne gibi sıkıntılar ile karşılaşıldığı, bu faaliyetlerin öğretmenler arası iletişimi nasıl etkilediği, bu faaliyetlerin Sosyal Bilgiler alanına ne gibi katkı sağladığı konuları üzerine Sosyal Bilgiler öğretmenlerinin görüş ve düşüncelerinin ortaya konması amaçlanmıştır. 


\section{Araştırmanın Yöntemi}

Araştırmada nitel araştırma tekniklerinden olgubilim modeli uygulanmıştır. Olgubilim modeli, farkında olduğumuz lakin detaylı ve ayrıntılı bir şekilde bilgi sahibi olmadığımız konular hakkında yaptığımız bilimsel araştırmalardır (Yıldırım ve Şimşek, 2008: 72).

\section{Çalışma Grubu}

Çalışma grubu oluşturulurken amaçsal örneklem yöntemlerinden kolay ulaş1labilir veya elverişli örneklem yöntemine başvurulmuştur. Bilindiği gibi bu örneklem yönteminde kolay olanı seçmek, çaba, zaman ve paradan tasarruf sağlamak ön plandadır (Baltacı, 2018: 246). Amaçsal örneklemde; derinlemesine araştırma yapmak amacıyla bilgi açısından zengin durumlar seçilmektedir (Büyüköztürk, Kılıç Çakmak, Akgün, Karadeniz ve Demirel, 2008). Araştırmanın çalışma grubunu Manisa ili Kula ilçesinde görev yapan 13 Sosyal Bilgiler öğretmeni (Erkek=7, Kadın=6) oluşturmaktadır. $\mathrm{Bu}$ seçimde öğretmenlere ulaş1labilirlik ve öğretmenlerin mülakat sorularına verebilecekleri cevaplar göz önünde bulundurulmuştur.

\section{Verilerin Toplanması ve Analizi}

Araştırmaya Kula ilçesinde bulunan 9 ortaokul dahil edilmiş ancak 8 ortaokuldan veri alınabilmiştir. 13 Sosyal Bilgiler öğretmeni ile görüşmeler gerçekleştirilmiştir. Verilerin toplanması için araştırmacılar tarafından hazırlanmış olan yarı yapılandırılmış görüşme formu kullanılmıştır. Yarı yapılandırılmış görüşme formu alanyazın taraması yapılarak hazırlanmış ve Sosyal Bilgiler alanında uzman 3 akademisyenin görüşleri alınarak son hali verilmiş ve uygulanmıştır. Sosyal Bilgiler alanında uzman 3 akademisyenin görüşlerinin alınmasıyla araştırmanın geçerlik ve güvenirliği arttırılmak istenmiştir. Yarı yapılandırılmış görüşme formu ile elde edilen veriler bilgisayar ortamında metin haline getirilerek, benzer verileri, görüşleri ve kavramları bir araya getirmek amacıyla içerik analizine tabi tutulmuştur (Yıldırım ve Şimşek, 2008: 163).

Araştırmaya katılan Sosyal Bilgiler öğretmenlerinin görüşme formundaki sorulara verdikleri cevaplar ilk önce 48 kodda toplanmış, daha sonra ilişkilendirilen bu kodlar 19'a indirilmiştir. Bu kodlardan en önemlileri şunlardır: mesleki çalışma faaliyetleri, geziler, mesleki gelişim, iletişim ve birliktelik, maddiyat, iletişim ve işbirliği, planlama ve değerlendirme, iletişimi arttırma, kendini geliştirme, etkinlik ve faaliyet, kitap okuma ve müzakere, uzman ve akademisyen vb.

\section{Bulgular}

$\mathrm{Bu}$ bölümde Manisa ili Kula ilçesinde görev yapan Sosyal Bilgiler öğretmenlerinin öğretmenlik mesleği seminerleri konusuna ilişkin düşünce ve görüşlerine yer verilmiştir. Araştırmaya katılan öğretmenlerin mülakat sorularına verdikleri cevaplara ilişkin kodlamalar Tablo 1'de gösterilmiştir. 
Tablo 1. Sosyal Bilgiler öğretmenlerinin öğretmenlik mesleğine seminer konusu mülakat sorularına verdiği cevaplara ilişkin kodlar.

\begin{tabular}{|c|c|c|c|c|c|c|c|c|c|c|c|c|c|c|}
\hline \multirow{3}{*}{$\begin{array}{l}\text { Sorul } \\
\text { ar }\end{array}$} & \multirow{3}{*}{ Kodlar } & \multicolumn{13}{|c|}{ Öğretmenler } \\
\hline & & $\ddot{O}$ & Ö & Ö & Ö & Ö & $\ddot{O}$ & Ö & Ö & Ö & Ö1 & Ö1 & Ö1 & Ö1 \\
\hline & & 1 & 2 & 3 & 4 & 5 & 6 & 7 & 8 & 9 & 0 & 1 & 2 & 3 \\
\hline \multirow{2}{*}{$\begin{array}{l}1 . \\
\text { Soru }\end{array}$} & Mesleki Çalışma & $\mathrm{X}$ & $\mathrm{X}$ & $\mathrm{X}$ & & $\mathrm{X}$ & $\mathrm{X}$ & $X$ & $X$ & $X$ & $\mathrm{X}$ & $\mathrm{X}$ & $\mathrm{X}$ & $X$ \\
\hline & Geziler & $\mathrm{X}$ & $\mathrm{X}$ & & $\mathrm{X}$ & & & & & & $\mathrm{X}$ & $\mathrm{X}$ & $\mathrm{X}$ & \\
\hline \multirow[b]{2}{*}{$\begin{array}{l}2 . \\
\text { Soru }\end{array}$} & Mesleki Gelișim & $\mathrm{X}$ & & $\mathrm{X}$ & $\mathrm{X}$ & $\mathrm{X}$ & $\mathrm{X}$ & $\mathrm{X}$ & $\mathrm{X}$ & $\mathrm{X}$ & $\mathrm{X}$ & $\mathrm{X}$ & $\mathrm{X}$ & $\mathrm{X}$ \\
\hline & $\begin{array}{ll}\text { İletişim } & \text { ve } \\
\text { Birliktelik } & \end{array}$ & $\mathrm{X}$ & $\mathrm{X}$ & & $\mathrm{X}$ & $\mathrm{X}$ & $X$ & & $\mathrm{X}$ & & & $\mathrm{X}$ & & \\
\hline \multirow{3}{*}{$\begin{array}{l}3 . \\
\text { Soru }\end{array}$} & Maddiyat & & & $\mathrm{X}$ & $\mathrm{X}$ & & & & $\mathrm{X}$ & & & $\mathrm{X}$ & & \\
\hline & S1k1c1 Olmas1 & $X$ & & & & & & & & & & & $\mathrm{X}$ & $\mathrm{X}$ \\
\hline & $\begin{array}{ll}\text { Herhangi } & \text { Bir } \\
\text { Sikıntı Yok } & \end{array}$ & & $\mathrm{X}$ & & & $\mathrm{X}$ & $\mathrm{X}$ & $\mathrm{X}$ & & $X$ & $\mathrm{X}$ & & & \\
\hline $\begin{array}{l}4 . \\
\text { Soru }\end{array}$ & İletişim ve İşbirliği & $X$ & $\mathrm{X}$ & $\mathrm{X}$ & $\mathrm{X}$ & $\mathrm{X}$ & $X$ & $X$ & $X$ & $X$ & $\mathrm{X}$ & $\mathrm{X}$ & $\mathrm{X}$ & $X$ \\
\hline \multirow{3}{*}{$\begin{array}{l}5 . \\
\text { Soru }\end{array}$} & $\begin{array}{ll}\text { Planlama } & \text { ve } \\
\text { Değerlendirme } & \end{array}$ & & & $\mathrm{X}$ & $\mathrm{X}$ & & $X$ & $X$ & & & $\mathrm{X}$ & $\mathrm{X}$ & $X$ & \\
\hline & İletişimi Arttırma & $\mathrm{X}$ & & & & & & & $\mathrm{X}$ & & & & & $\mathrm{X}$ \\
\hline & Kendini Geliştirme & & $\mathrm{X}$ & & & $\mathrm{X}$ & & & & $\mathrm{X}$ & & & & \\
\hline \multirow{3}{*}{$\begin{array}{l}6 . \\
\text { Soru }\end{array}$} & Etkinlik ve Faaliyet & $\mathrm{X}$ & & & $\mathrm{X}$ & $\mathrm{X}$ & & & $\mathrm{X}$ & & & $\mathrm{X}$ & & \\
\hline & $\begin{array}{l}\text { Kitap Okuma ve } \\
\text { Müzakere }\end{array}$ & & $\mathrm{X}$ & & & & & & & $\mathrm{X}$ & & & $\mathrm{X}$ & \\
\hline & $\begin{array}{ll}\text { Uzman } & \text { ve } \\
\text { Akademisyen } & \end{array}$ & & & $\mathrm{X}$ & & & $X$ & $\mathrm{X}$ & & & $X$ & & & $X$ \\
\hline
\end{tabular}

Araştırmanın ilk sorusu: öğretmenlik mesleği seminerleri kapsamındaki faaliyetleriniz nelerdir? sorusuna araştırmaya katılan 13 Sosyal Bilgiler öğretmeninden 7'si planlama, değerlendirme, video izleme, sunum yapma, kitap okuma gibi mesleki çalıșma faaliyetleri olduğunu ifade etmiştir. K.7 "Eğitim-öğretim faaliyetleri ile ilgili gerekli planlamaları yapıyoruz. Ayrıca yılsonu seminerlerinde dönem içerisinde yapılan etkinliklerin ve faaliyetlerin sonuçlarının değerlendirmesini yapıyoruz.", K.9 "Seminer dönemlerinde genelde bir konu üzerinde araştırma yapıp sunum yapmaktayız. Araştırdı̆̆ımız konu hakkında derinlemesine bilgileri öğretiyoruz. Geçen dönem mesleki çalışmam; Fuat Sezgin: Bilim Tarihi Sohbetleri idi."şeklinde görüş dile getirmiş̧tir. Araştırmaya katılan 1 Sosyal Bilgiler öğretmeni piknik, doğa yürüyüşü, müze ziyaretleri kapsamında ki geziler diye 
cevap vermiştir. K.4 "2018-2019 eğitim öğretim yılı seminer çalışmasına kadar çok verimli olmayan bir seminer dönemi geçmekteydi. Fakat bu yıl daha etkin, öğretmenleri kaynaştırıcı etkinliklerle planlanmış. Okul imkanı dahilinde yapılan etkinlikler ögretmenler arası iletişi arttırmaktadır." şeklinde görüş belirtmiştir. Araştırmaya katılan 5 Sosyal Bilgiler öğretmeni de hem mesleki çalışma faaliyetleri hem de geziler olduğunu vurgulamıştır. K.2 "Hizmet içi eğitim seminerleri kapsamında kitap okuma faaliyetleri gerçekleştiriyoruz. Bunun yanı sıra doğa yürüyüşleri ve geziler yapıyoruz.”, K10 "Her öğretmene eğitimle ilgili konular verilip sunum yapıllyor. Ayrıca bu sene doğa yürüyüşü ve kültürel gezi etkinlikleri yapıldı.", K.12 ise "Ders kazanımlarına yönelik etkinlik üretildi. Güncellenen ögretim programlarının program geliştirme ilkeleri olan "genel amaçlar ile içerik uyumu" değerlendirildi. Müzede eğitim etkinliği çerçevesinde eğitim müzeleri, tabiat müzeleri, bilim müzeleri, tarihi mekanların yeri $v b$. gezildi. Doğa yürüyüşü (oryantiring etkinliği) öğretmenlerin motivasyonunun ve kurumsal aidiyet duygusunun arttırlması amacıyla gerçekleştirildi." şeklinde görüş bildirmiştir.

Araştırmanın ikinci sorusu: öğretmenlik mesleği seminerleri kapsamındaki faaliyetlerin faydaları nelerdir? sorusuna araştırmaya katılan 13 Sosyal Bilgiler ögretmeninden 6's1 plan yapılması, değerlendirme yapılması, bilgilerin verilmesi, eksikliklerin giderilmesi gibi mesleki gelișime katk1 sağladığını söylemiştir. K.3 “Öğretmenlerin mesleki gelişimi açısından seminerlerin faydalı olduğunu düşünüyorum. Faaliyetlerimiz kapsamında sunumlar bilgilendirmeler yapıllyor. Mesleki gelişime olumlu katkısı oluyor.", K.7 "Dönem başında o yıl içerinde branş olarak ne gibi çalışmaların yapılacağına dair planlama yapılması, diğer branş öğretmenleri ile işbirliği yapılması ve ortak konularda fikir alışverişinde bulunulması, genel değerlendirme.", K.10 "Mesleki anlamda farklı konu ve alanlarda bilgi sahibi edinilmesini sağllyor." şeklinde görüş belirtmiştir. Araştırmaya katılan 1 Sosyal Bilgiler öğretmeni kaynaştırıcı olması, eğlenceli olması, stresi atması, motivasyonu artırması gibi iletișim ve birlikteliği arttırdığını ifade etmiştir. K.2 "Öğretmenler arası iletişimin ve birlikteliğin kuvvetlenmesi, istişare imkanının doğması gibi faydalar var." şeklinde görüş dile getirmiştir. Araştırmaya katılan 6 Sosyal Bilgiler öğretmeni hem mesleki gelișimi hem de iletișim ve birlikteliği arttırdığını vurgulamıştır. K.5 “Öğretmenlik mesleği seminerleri kapsamındaki faaliyetler ögrretmenlerin mesleki açıdan kendine gelişstirmelerini, öğretmenler arasındaki iletişimin kuvvetlenmesini sağlamaktadır.”, K.6 “Eksik kaldı̆̆ımız veya bilmediğimiz alanlarda bilgi sahibi oluyoruz. Öğretmenler arasında kaynaşma artıyor. Yapılan etkinliklerle birbirini daha iyi tanıma oluyor.”, K.8 ise “Öğretmenler arası iletişim ve işbirliğinin arttı̆ıın düşünüyorum. Doğru bir şekilde uygulandiğında bu faaliyetlerin ögretmenlerin motivasyonlarını arttırdıklarını düşünüyorum. Alan dışı konularda ögrencilere yardımcı olabilecek, rehberlik edebilecek bilgiler edinildiğini söyleyebilirim." şeklinde söylemde bulunmuştur.

Araştırmanın üçüncü sorusu: öğretmenlik mesleği seminerleri gerçekleşirken karşılaştığınız sıkıntılar nelerdir? sorusuna araştırmaya katılan 13 Sosyal Bilgiler öğretmeninden 4'ü okulların fiziki 
yetersizliklerini dile getirerek maddiyat olduğunu vurgulamıştır. K.4 "Planlanan etkinlikler için daha çok maddi olanaklar sağlansa daha kapsamlı bir planlama yapılsa daha etkili olacaktır. Örneğin; müze ziyareti etkinliği var. Fakat ilçemizde müze yok. Yakın ilçe ya da illere gitmek için de maddi imkan sağlanmall.”, K.8 “Okulumuzda özellikle birlikte faaliyet yapılabilecek fiziksel donanıma eksik olduğunu düşünüyorum.”, K.11 “Bulunduğumuz ilçede müze olmadı̆̆ı ve ilçe (bakanlık tarafindan) maddi alt yapıyı hazırlamadığ için istenilen düzeyde gerçekleştirilemedi." şeklinde görüş belirtmiş̧tir. Araştırmaya katılan 3 Sosyal Bilgiler öğretmeni konuların güncel olmamasından dolayı ve sıkıcı olması diye cevap vermiştir. K.1 "Slkıcı olabiliyor zaman zaman.", K.12 "Yapılan bazı çalışmalar tekrar olabiliyor. Güncel konular daha yararlı olur.”, K.13 “Araştırma, tarihi ve doğal güzellikleri gezme faaliyetleri olmadiğından stradan bir seminer dönemi. Dolayısıyla zaman zaman sıkıcı geçmektedir." şeklinde görüş dile getirmiştir. Araştırmaya katılan 6 Sosyal Bilgiler öğretmeni ise Öğretmenlik mesleği seminerleri gerçekleşirken herhangi bir sıkıntı ile karşılaşmadıklarını ifade etmiştir. K.5 “Öğretmenlik mesleği seminerlerini gerçekleştirirken herhangi bir sıkıntı yaşamıyoruz.”, K.6 "Genel anlamda mesleğimizi etkileyecek sıkıntı yaşanmamıştır.", K.7 "Seminerlerde mesleki olarak ve branş olarak herhangi bir problemle karşılaşmadık." şeklinde görüş bildirmiştir.

Araştırmanın dördüncü sorusu "Öğretmenlik mesleği seminerleri kapsamında öğretmenler arası iletişim hakkında bilgi verir misiniz? sorusuna araştırmaya katılan 13 Sosyal Bilgiler öğretmeninin her biri, seminerler kapsamındaki sohbet ve kaynaşma gibi etkinliklerin öğretmenler arası iletişim ve ișbirliğini arttırdığını vurgulamışlardır. K.3 "Aynı kurumda çalışan meslektaşlar açısından iletişimin ve işbirliğinin daha da artmasını sağllyor.", K.5 "Öğretmenlik mesleği seminerleri özellikle zümre öğretmenler arasındaki iletişimin artmasını sağlamaktadır. Sene içindeki çalışmalar ve sonuçlart ile ilgili iletişim halinde olan öğretmenlerin bir sonraki yıl çalışmalarındaki verim artmaktadır.”, K.7 “Genel olarak tüm branş öğretmenleri ders içeriği konusunda ve öğretim yöntem teknikleri konusunda fikir alış verişinde bulunmaktadırlar. Ayrıca öğrenciler hakkında değerlendirmelerde bulunmaktadırlar. İş birliğine dayalı bir ĕgitim-öğretim faaliyeti yürütülmektedir.”, K.8 “Bu dönemde öğretmenler arasındaki iletişimin ve işbirliğinin daha da arttığın düşünüyorum.", K.10 "Seminerler öğretmenler arast iletişi arttırıcı bir özelliğe sahiptir.", K.13 ise "Seminerlerin en önemli yanı belki de bu. Bu dönemde ögretmenler arasındaki iletişim artmakta ve olumlu geçmektedir." şeklinde görüş belirtmiştir.

Araştırmanın beşinci sorusu: öğretmenlik mesleği seminerlerinin Sosyal Bilgiler alanına katkıları nelerdir? sorusuna araştırmaya katılan 13 Sosyal Bilgiler öğretmeninden 7'si Sosyal Bilgiler dersinin planlanmasına ve değerlendirmesine katkı sağladığını ifade etmiş̧tir. K.11 "Kazanım değerlendirmesi, Sosyal Bilgiler planlarının gözden geçirilmesini sağladı. Sene sonu zümre değerlendirmesinin yapılması, yıl içinde yaşadı̆̆ımı sorunların değerlendirilmesini sağladı. Doğa yürüyüşü, müzede öğrenelim, bizim branşımızla iç içe konular olduğu için oldukça ögrretici oldu.", $\mathrm{K} .12$ "Yıl boyunca hedeflenen kazanımların yerine getirilip geliştirilmediğini, yaşanan aksaklıkları 
görebilmeyi sağllyor. Ne gibi tedbirler alınacağını görebiliyoruz. Ayrıca yıl içinde yapacă̆ımız çalışmaları, gerekli araç-gereçleri tespit etmeyi, daha verimli bir eğitim öğretim için yapılacak çalışmaları önceden planlamayı sağllyor." şeklinde görüş belirtmiştir. Araştırmaya katılan 3 Sosyal Bilgiler öğretmeni öğretmenler arası iletișimi arttırdığını vurgulamıştır. K.1 "İletişi arttırarak Sosyal Bilgiler dersindeki sorunların çözümünü kolaylaştırmaktadır.”, K.13 “Öğretmenlik mesleği seminerlerinin Sosyal Bilgiler alanını desteklemelidir. Doğa yürüyüşü, tarihi ve doğal güzelliklerin keşfi gibi geziler seminer programları boyunca ögretmenler arası iletişimi arttırmaktadır." şeklinde görüş dile getirmiştir. Araştırmaya katılan 3 Sosyal Bilgiler öğretmeni ise bu seminerlerin öğretmenlerin kendilerini geliștirme firsatı sunduğunu söylemiştir. K.2 "Öğretmenlerin bu dönemde yapacă̆ı, okumalar ve geziler sayesinde Sosyal Bilgiler öğretmenlerinin de ufkunun geliştiğini, dünya görüşünün zenginleştiğini söyleyebiliriz.”, K.9 “Kendi alanımızla ilgili seminer konularını araştırıp bilgilerimizin tazelenmesini sağllyoruz. Sosyal Bilgiler öğretmenleri olarak kendi alanımızdaki konuları derinlemesine araştırıp ögrretmen arkadaşlarımızla da paylaşıyoruz. Böylece bilgilerimizi arttırlyoruz." şeklinde görüş bildirmiştir.

Araştırmanın son sorusu: öğretmenlik mesleği seminerleri hakkındaki görüşleriniz nelerdir?” sorusuna araştırmaya katılan 13 Sosyal Bilgiler öğretmenlerinden 6's1; piknik, doğa yürüyüşü, müze ziyareti gibi etkinlik ve faaliyetlere daha fazla yer verilebileceğini söylemiştir. K.1 "Piknik gibi kaynaşma programları arttırllabilir.", K.4 "Sosyal Bilgiler öğretmeni olarak tarihe ve doğal güzelliklere geziler planlanıp, ilçe Sosyal Bilgiler öğretmeni olarak daha verimli seminerler olabileceğini düşünüyorum. Tarihi ve doğal güzellikleri yerinde görmek, bilgi sahibi olmak daha da bilgilenmek öğrencilere de olumlu yansıyacaktır." şeklinde görüş belirtmiştir. Araştırmaya katılan 4 Sosyal Bilgiler öğretmeni uzman ve akademisyenlerle ișbirliğinin yapılabileceğini vurgulamıştır. K.6 "Her branş ile ilgili üniversitelerin ilgili bölümlerinden uzmanlar getirtilerek bilgilendirme çalışmaları yapılabilir. Her branştan öğretmenler merkezi olarak belli yerlerde toplanarak alanları ile ilgili seminer alabilirler.", K.7 "Üniversitelerde görevli akademik personellerin o ildeki il ya da ilçe merkezindeki ögrretmenlerin bir merkezde toplanmaları sağlanabilir ve akademik personel tarafindan branş bazında bilgilendirme yapılabilir." biçiminde ifade kullanmıştır. Araştırmaya katılan 3 Sosyal Bilgiler öğretmeni ise kitap okuma ve müzakere gibi etkinliklerin sayısının arttırılabileceğini ifade etmiştir. K.2 "Daha fazla kitap okuma faaliyetlerinin olmasını, bununla beraber okuma kitaplarının mütalaası için planlamaların yapılmasını tavsiye edebilirim.”, K.12 "Dünyada eğitim ile ilgili örnek uygulamalar her açıdan incelenerek tartışılıp müzakere edilebilir." şeklinde görüş dile getirmiştir.

\section{Sonuç}

$\mathrm{Bu}$ araştırma; Sosyal Bilgiler öğretmenlerinin öğretmenlik mesleği seminerleri kapsamındaki faaliyetlerinin neler olduğunu, bu faaliyetlerin faydalarının neler olduğu, bu faaliyetleri gerçekleştirirken ne gibi sıkıntılar ile karşılaşıldığı, bu faaliyetlerin Sosyal Bilgiler alanına katkılarının 
neler olduğu gibi konular ortaya koymayı amaçlamıştır. Genel olarak bu araştırma ile Sosyal Bilgiler öğretmenlerinin öğretmenlik mesleği seminerleri hakkındaki görüş ve düşünceleri ortaya konmuştur.

Araştırma kapsamında ilk soru: “öğretmenlik mesleği seminerleri kapsamındaki faaliyetleriniz nelerdir?" sorusuna araştırmaya katılan Sosyal Bilgiler öğretmenleri; piknik, doğa yürüyüşü, müze ziyaretleri kapsamındaki geziler ile planlama, değerlendirme, video izleme, sunum yapma, kitap okuma gibi mesleki çalışma faaliyetler olduğunu belirtmişlerdir. Öğretmenlik mesleği seminerleri kapsamında genellikle piknik, doğa yürüyüşü, müze ziyareti gibi etkinliklere daha çok yer verildiği dile getirilmiştir.

Araştırmanın ikinci sorusu: "öğretmenlik mesleği seminerleri kapsamındaki faaliyetlerin faydaları nelerdir?" sorusuna araştırmaya katılan Sosyal Bilgiler öğretmenleri; plan yapılması, değerlendirme yapılması, bilgilerin verilmesi, eksikliklerin giderilmesi gibi mesleki gelişime katk1 sağladığını belirtmişlerdir. Ayrıca kaynaştırıcı olması, eğlenceli olması, stresi atması, motivasyonu artırması gibi iletişim ve birlikteliği arttırdığını ifade etmişlerdir. Öğretmenlik mesleği seminerleri sayesinde gerçekleştirilen bu etkinlikler sayesinde hem öğretmenlerin bilgi bakımdan kendilerini geliştirdikleri hem de gelecek yılların plan ve programlarını yaparak mesleki gelişimlerini arttırmayı amaçladıkları dile getirilmiştir.

Araştırmanın üçüncü sorusu: "öğretmenlik mesleği seminerleri gerçekleşirken karşılaştığınız sıkıntılar nelerdir?" sorusuna araştırmaya katılan Sosyal Bilgiler öğretmenlerinin yaklaşık yarısı; okulların fiziki yetersizliklerini dile getirerek maddi imkan ve konuların güncel olmamasından dolayı sıkıcı olmasını dile getirirken, araştırmaya katılan diğer Sosyal Bilgiler öğretmenleri ise; öğretmenlik mesleği seminerleri gerçekleşirken herhangi bir sıkıntı ile karşılaşmadıklarını ifade etmişlerdir. Öğretmenlik mesleği seminerler programları sayesinde dile getirilen bu sıkıntıların tamamı olmasa bile bir kısmının giderilmesi adına çalışmaların yapıldığı ve öğretimin kalitesinin arttırılmak istendiği de vurgulanmıştır.

Araştırmanın dördüncü sorusu: "öğretmenlik mesleği seminerleri kapsamında öğretmenler arası iletişim hakkında bilgi verir misiniz?” sorusuna araştırmaya katılan Sosyal Bilgiler öğretmeninin her biri; seminerler kapsamındaki sohbet ve kaynaşma gibi etkinliklerin öğretmenler arası iletişim ve işbirliğini arttırdığını vurgulamışlardır. Seminer programları haricinde öğretmenlerin genellikle kendi dersleriyle meşgul oldukları ve öğretmenlerin birbirleri ile sosyal etkileşim içinde pek olmadıkları vurgulanmıştır. Öğretmenlik seminerleri programları sayesinde öğretmenler arası etkileşimin arttığını ve çok güzel arkadaşlıkların oluş̧tuğu dile getirilmiştir.

Araştırmanın beşinci sorusu: "öğretmenlik mesleği seminerlerinin Sosyal Bilgiler alanına katkıları nelerdir?” sorusuna araştırmaya katılan Sosyal Bilgiler öğretmenleri sırasıyla; Sosyal Bilgiler dersinin planlanmasına ve değerlendirmesine katkı sağladığını, öğretmenler arası iletişimi arttırdığını ve öğretmenlerin kendilerini geliştirme firsatı sunduğunu söylemiştir. Öğretmenlik mesleği seminerleri 
sayesinde öğrencilerin başarılarının arttırılması konusunda öğretmenler arası bilgi alışverişinde bulunulduğu ve gelecek eğitim-öğretim yılları için güzel fikirlerin ortaya çıktığı belirtilmiştir.

Araştırmanın son sorusu: “öğretmenlik mesleği seminerleri hakkındaki görüşleriniz nelerdir?” sorusuna araştırmaya katılan Sosyal Bilgiler öğretmenlerinin yarıya yakını; piknik, doğa yürüyüşü, müze ziyareti gibi etkinlik ve faaliyetlere daha fazla yer verilebileceğini söylemiştir. Araştırmaya katılan diğer Sosyal Bilgiler öğretmenleri ise; uzman ve akademisyenlerle işbirliğinin yapılabileceğini ve kitap okuma ile müzakere gibi etkinliklerin sayısının arttırılabileceğini ifade etmiştir. Öğretmenlik seminerleri kapsamında Sosyal Bilgiler öğretmenleri genellikle seminer programlarında teorik bilgilerden ziyade uygulamalı ve daha çok etkinliklerle gerçekleştirilen seminer programlarına yer verilmesi gerektiği üzerinde durmuşlardır. Ayrıca araştırmaya katılan Sosyal Bilgiler öğretmenleri seminer programları dahilinde uzman ve akademisyenlerle işbirliği yapılmasının seminer programlarının kalitesini arttırılacağını vurgulamışlardır.

\section{Tartışma}

Öğretmenlik mesleği seminerleri konusu üzerine yapılan çalışmalara bakıldığında bu konuda yapılan çalışmaların sayısının yeteri kadar olmadığı, genellikle yazarların hizmet içi eğitim konusunda araştırmalara yöneldiği görülmektedir. Sosyal Bilgiler öğretmenlerinin bu konu üzerine görüşlerini ortaya koyan çalışmalara ise rastlanılmamıştır. Az sayıda olan öğretmenlik mesleği seminerleri konusu üzerine yapılan çalışmalara baktığımızda; Milli Eğitim Bakanlığı Araştırma ve Geliştirme Dairesi Başkanlığı'nın (2006) yılında yayınladığı "ỉlköğretim Okulu Öğretmenlerinin Yaptıkları Mesleki Seminer Çalışmalarının Değerlendirilmesi” adlı çalışmasında MEB’e bağlı ilköğretim okullarında görev yapan öğretmenlerin öğretim yılı başında, sürecinde ve sonunda yapmış oldukları mesleki çalışmaların değerlendirilmesi amaçlanmıştır. Araştırmanın sonunda; seminer konularının öğretmenlerin ihtiyaçlarına göre belirlenip her yıl güncellenmesinin ve teknolojik gelişmelere açık olmasının gerekliliği ifade edilmiştir. Ayrıca müfettişlerin sayısının arttırılarak öğretmenlere daha fazla rehberlik yapılması veya öğretmenlerin iş yüklerinin azaltılmasının gerekliliği vurgulanmıştır. Yaptığımız çalışmada da öğretmen adaylarının vurguladığ 1 noktalardan biri derste işlenen konuların güncel olmaması ve derslerin sıkıcı geçmesiydi. Seminer çalışmalarının değerlendirilmesine ilişkin ortaya konan bu iki çalışmada da derslerde işlenen konuların güncel olması vurgulanmıştır.

Gültekin, Güvey Aktay ve Gültekin (2018: 482), “ïlköğretimde Mesleki Çalışma (Seminer) Dönemi Uygulamaları” adlı çalışmalarında; ilköğretim kurumlarında görev yapan öğretmenlerin seminer dönemindeki mesleki çalışmalarına yönelik görüşlerini belirlemeyi amaçlamışlardır. Araştırmanın sonunda öğretmenlerin mesleki çalışmaları esnasında akademik yıla ilişkin hazırlıklarını paylaştıkları, araştırma-incelemeye yönelik etkinlikleri yaptıkları, seminer sürelerinin azaltılması gerektiğini ve seminerlerin branşlara yönelik olarak uzmanlar eşliğinde verilmesi gerektiği görüşleri ortaya çıkmıştır. Bizim gerçekleştirmiş olduğumuz çalışmada da öğretmenlik mesleği seminerleri 
kapsamında; piknik, doğa yürüyüşü, müze ziyaretleri kapsamındaki geziler ile planlama, değerlendirme, video izleme, sunum yapma, kitap okuma gibi mesleki çalışma faaliyetlerinin olduğu dile getirilmiştir. Ayrıca öğretmenlik mesleği seminerleri kapsamında gerçekleştirilen etkinlik faaliyetlerde uzman ve akademisyenlerle işbirliği yapılarak gerçekleştirilen eğitimin içerik kalitesi arttırıla bilineceği ifade edilmiştir. .gerçekleştirilen iki çalışmada da seminerlerin uzmanlar eşliğin de daha profesyonelce verilmesi gerektiği üzerinde durulmuştur.

Genç (2015: 8) yılında yayınladığı "Mesleki Gelişim Seminer Çalışmalarının Öğretmenler Tarafından Değerlendirilmesi Örneklemi” adlı yüksek lisans tez çalışmasında; ilkokul ve ortaokullarda görev yapan öğretmenlerin mesleki gelişim seminer çalışmalarına yönelik görüşlerini belirlemeyi amaçlamıştır. Araştırmanın sonunda mesleki gelişim seminerlerinin amaca ulaşan program olduğu, içeriklerinin yetersiz ve bilinen konuların tekrarı olduğu, sürecin verimsiz ve zaman kaybı olduğu, çalışma ortamının teknolojiden uzak olduğu, öğretmen ihtiyaçlarına uygun hazırlanmadığı, uygulamadan uzak ve formalite olduğu sonuçları ortaya çıkmıştır. Gerçekleştirmiş olduğumuz bu çalışmada ise Sosyal Bilgiler öğretmenleri; öğretmenlik mesleği seminerlerinin Sosyal Bilgiler dersinin planlanmasına ve değerlendirmesine katkı sağladığını, öğretmenler arası iletişimi arttırdığını ve öğretmenlerin kendilerini geliştirme firsatı sunduğunu söylemiştir. Görüldüğü gibi bu iki çalışmada birbirinden tamamen farklı sonuçlar ortaya çıkmıştır.

Gerçekleştirmiş olduğumuz bu çalışmada Sosyal Bilgiler öğretmenlerinin öğretmenlik mesleği seminerleri konusundaki görüş ve düşüncelerinin ortaya konması amaçlanmıştır. Araştırmadan elde edilen sonuçlara göre öğretmenlik mesleği seminerleri kapsamında piknik, doğa yürüyüşü, müze ziyaretleri gibi etkinliklere yer verildiği ve seminerlerin öğretmenlerin mesleki gelişimlerine katk1 sağlayıp öğretmenler arası iletişim ve birlikteliği arttırdığını ifade edilmiştir. Ayrıca öğretmenlik mesleği seminerleri kapsamında uzman ve akademisyenlerle daha çok etkileşim halinde olunup piknik, doğa yürüyüşü, müze ziyareti gibi etkinlik ve faaliyetlerin öğretmenlik mesleği seminerleri kapsamında daha fazla yer verilmesinin daha yararlı olabileceği dile getirilmiştir.

Öneriler

Elde edilen bulgulardan yola çıkılarak şu önerilerde bulunulmuştur:

- $\quad$ Sosyal Bilgiler öğretmelerinden 6'sı; piknik, doğa yürüyüşü, müze ziyareti gibi etkinlik ve faaliyetlere daha fazla yer verilebileceğini ifade ettiği görülmüştür. Dolayısıyla, seminer faaliyetleri kapsamında piknik, doğa yürüyüşü, müze ziyareti gibi etkinlikler artırılarak öğretmenlerin seminerlere ilişkin motivasyonları sağlanabilir.

- Araştırmaya katılan Sosyal Bilgiler öğretmenlerinden 5'i öğretmenlik mesleği seminerleri kapsamında uzman ve akademisyenlerle ortaklaşa seminer faaliyetlerinin gerçekleştirilmesinin faydalı olacağını dile getirmiştir. Bu sebeple öğretmenlik mesleği seminerleri 
kapsamında gerçekleştirilen etkinlik ile faaliyetlerde uzman ve akademisyenlerle işbirliği yapılarak gerçekleştirilen eğitimin içerik kalitesi arttırılabilir.

- $\quad$ Araştırmaya katılan Sosyal Bilgiler öğretmenlerinden 3'ü öğretmenlik seminerleri kapsamında kitap okuma faaliyetlerini gerçekleştirdiklerini belirtmişlerdir. Öğretmenlik mesleği seminerleri kapsamında kitap okuma ve müzakere gibi eğitim faaliyetlerinin sayısı arttırılabilir.

- $\quad$ Araştırmaya katılan Sosyal Bilgiler öğretmeninin her biri; seminerler kapsamındaki sohbet ve kaynaşma gibi etkinliklerin öğretmenler arası iletişim ve işbirliğini arttırdığını vurgulamışlardır. Aynı il ya da ilçedeki ortaokullar ile ortaklaşa seminer programları hazırlanarak hem ortaklaşa işbirliği yapılabilir hem de öğretmenler arası birliktelik arttırılabilir.

- Araştırmaya katılan Sosyal Bilgiler öğretmeninden 4'ü yarısı okulların maddi bakımdan yetersiz olduğunu dile getirmiştir. Milli Eğitim Bakanlığı seminer programları için bütçe ayırarak seminer programlarına maddi destek sağlaması önerilebilir.

- $\quad$ Seminer programlarına öğrenci velileri de dahil edilerek onların görüşleri de alınabilir. Böylece öğrenci velileri öğrencilerin derslerine karşı daha ilgili olması da sağlanabilir.

- $\quad$ Öğretmenlik mesleği seminerlerine katılan her bir öğretmen her seminer döneminin sonunda seminer döneminin nasıl geçtiğini artılarıyla eksileriyle il ve ilçe Milli Eğitim müdürlüklerine rapor edebilir. 


\section{Kaynakça}

Aydın, Nuray ve Yılmaz, Ayhan (2010) "Yapılandırmacı Yaklaşımın Öğrencilerin Üst Düzey Bilişsel Becerilerine Etkisi”. Hacettepe Üniversitesi Eğitim Fakültesi Dergisi, 39. 57-68.

Baltacı, Ali (2018) "Nitel Araştırmada Örneklem Yöntemleri ve Örnek Hacmi Sorunsalı Üzerine Kavramsal Bir İnceleme”. Bitlis Eren Üniversitesi Sosyal Bilimler Enstitüsü Dergisi, 7(1). 231-274.

Başar, Erdoğan (2007) Eğitim Bilimine Giriş, Ankara: PegemA,

Büyüköztürk, Ş., Kılıç Çakmak, E., Akgün, Ö.E., Karadeniz, Ş. \& Demirel, F. (2008) Bilimsel Araştırma Yöntemleri. Ankara: Pegem Yayınları.

Fidan, Nurettin (2012) Okulda Öğrenme ve Öğretme Ankara: Pegem Akademi,

Genç, Gülin Sevi (2015) Mesleki Gelişim Seminer Çalışmalarının Öğretmenler Tarafindan Değerlendirilmesi Örneklemi. Yüksek Lisans Tezi, İstanbul Aydın Üniversitesi Sosyal Bilimler Enstitüsü İşletme Ana Bilim Dalı İşletme Yönetimi Bilim Dalı, İstanbul.

Gültekin, M., Güvey Aktay, E. ve Gültekin I. (2018) "İlköğretimde Mesleki Çalışma (Seminer) Dönemi Uygulamaları". AJESI- Anadolu Journal of Educational Sciences International, 8(2). 482-513.

Keskin, Yusuf (2009) "Türkiye'de İlkokul Programlarında Yer Alan Sosyal Bilgiler İçerikli Derslere Ait Öğretim Programlarının Gelişimine Tarihsel Bir Bakış". Türkiye Sosyal Araştırmalar Dergisi, 13(2). 107-130.

Milli Eğitim Bakanlığı (2006) “ỉlköğretim Okulu Öğretmenlerinin Yaptıkları Mesleki Seminer Çalışmalarının Değerlendirilmesi, Milli Eğitim Bakanlığı Eğitimi Araştırma ve Geliştirme Dairesi Başkanlığı, Ankara; https://www.meb.gov.tr/earged/earged/senebasi_seminer_calismalari.pdf 02.10.2019

Milli Eğitim Bakanlığı Özel Öğretim Kurumları Genel Kurulu (2008) Özel Eğitim Rehabilitasyon Merkezi Zihinsel Engelli Bireyler Destek Eğitim Program,, Ankara. https://orgm.meb.gov.tr/meb _iys_dosyalar/2013_09/04010347_zihinselengellibireylerdestekeitimprogram.pdf 02.10.2019

Nalçacı, Ahmet (2001) Cumhuriyetten Günümüze İlköğretim Sosyal Bilgiler Programındaki Değişmelerin Değerlendirilmesi. Yüksek Lisans Tezi, Atatürk Üniversitesi Sosyal Bilimler Enstitüsü İlköğretim Anabilim Dal, Erzurum.

Şahin, Cengiz (2001) "Sosyal Beceri ve Sosyal Yeterlilik”. G.Ü. Kırşehir Eğitim Fakültesi Dergisi, 2(1). 9-19.

Yıldırım, Ali ve Şimşek Hasan (2008) Sosyal Bilimlerde Nitel Araştırma Yöntemleri. Ankara: Seçkin Yayıncilik. 